\title{
MICRO-CELEBRITIES' CONCEPT OF HIJRAH: A CRITICAL METAPHOR ANALYSIS
}

\author{
Zainur Rofiq \\ UIN Maulana Malik Ibrahim \\ Malang, East Java, Indonesia \\ zainurrofiq@uin-malang.ac.id
}

\begin{abstract}
The integration between the Conceptual Metaphor Theory (CMT) and the pragmatic aspect of the metaphor usage has resulted in the emergence of the Critical Metaphor Analysis (CMA) approach to examine metaphors in public discourse. By applying this approach, the present study explores the types of metaphors in Ustadz Hanan Attaki (henceforth UHA) and Ustadz Abdul Somad (Henceforth UAS) both English and Indonesian speech corpora on economic discourses and their possible latent ideologies. The results also indicate that some (linguistic) realizations of conceptual mappings of the metaphors in UHA and UAS' corpus are used to evoke the emotion and the soul of their audiences. Further, the current study also shows that both UHA and UAS share similar collectivism/jama'ah ideological values manifested through the journey and battle metaphors dataset.
\end{abstract}

Keywords: Critical Discourse Analysis (CDA), Critical Metaphor Analysis (CMA), Metaphor, Ideology

\section{INTRODUCTION}

Metaphor is the way of thinking about something and represent it in the form of utterances (Lakoff and Johnson, 1980). The identification of metaphor used in a utterance can be done through the use of Conceptual Metaphor Theory (henceforth CMT). The function of CMT is to connect between source domain and target domain in the target text (Lakoff, 1993). Source domain is the notion or ideology before it is formed into metaphorical utterance, while target domain is a result from that ideology that has become metaphorical utterance. Take, for example, a Charteris-Black' (2006) study in which he found that the source domain surrounding the issue of immigration in Britain was once conceptualized as a natural disaster, in this case is 'flood' or 'tide'. It is because, the coming of legal and illegal immigrations are assumed fluctuated similar to the characteristic of 'flood' or 'tide' that is hardly if ever predictable. The ultimate aim of such a metaphorical 
utterance was used for influencing the British public's belief about immigration proposed by right-wing politicians in British election campaign in 2005 (ibid.).

The current disruptive era of social media has given everyone the chance to become famous, and this has led to a new phenomenon called micro celebrity (Marwick \& Boyd, 2011). The presence of various social media platforms enables everyone to present and express themselves. Anyone can gain popularity if they have power on social media. Strength is measured through the number of followers in their social media accounts (Jargalsaikhan \& Korotina, 2016). The more followers a person has, the stronger the person's status in the media. To become a micro celebrity, one needs endeavors to be the center of attention among the social media users (Cultureshop, 2015). A figure can be called micro celebrity if $\mathrm{s} / \mathrm{he}$ has a very large number of followers and his/her name is known by many social media users. In addition to bringing up micro celebrities, such as celebgrams and celeb-tweets, social media also creates micro-celebrity ustadz figures.

The present study is aimed at investigating the use of metaphors in the two microcelebrity ustadz's dakwa on the concept of hijrah, namely Ust. Hanan Attaqi (henceforth called UHA) and Ust. Abdul Somad (henceforth called UAS). The motivations of this selection are, firstly, the fact that these figures' popularity is initially gained through the social media for their light but fully-loaded delivery on Islamic issues, particularly among the youth. Besides, secondly, they both seem to have authority on Islamic knowledge and related issues as they are graduates from prestigious Islamic universities in the MiddleEast.

Furthermore, by adopting the critical perspective proposed by Charteris-Black (2004), I expect to unveil the underlying intentions and implicit ideological motivations of each conceptualized metaphor by both ustadz to persuade the viewers of their dakwah. Although there have been many comparative studies with regard to metaphor analysis, most of them focused on analyzing metaphoric conceptualization of economic discourse in news media and political speeches corpora for comprehensively analyzing various discourses. Therefore, this study is also expected to show how discourses in Islamic dakwah and other discourses differ in conceptualizing reality metaphorically.

Therefore, on the basis of the background described above, the present study is aimed at investigating the conceptual metaphors used in the UHA and UAS' dakwah on the hijrah concept and providing any possible ideological explanations for their use of the operated conceptual metaphors. This study is interesting to be done because analyzing concept of hijrah from ulama who get its popularity through social media is an interesting discourse in this technology era.

\section{THEORETICAL FRAMEWORK}

Micro-Celebrity ustadz are typically identified by their lots of followers on social media, as well as footage of their dakwa on the social media timeline. However, the main concern lies in the fact that even ordinary people can get the status of celebrity-ustadz by utilizing the social media. The public cannot really objectively judge about the knowledge 
breadth or background of the micro-celebrity ustadz because the social media merely reveals the front stage, or the screen-look of a particular figure. Memorizing one or two Quranic verses or hadith, and possessing the persuasive 'rhetoric' of Islam, one can be easily recognized as ustadz in the social media users.

From this perspective, discourse creates social reality, which is practice, knowledge, ideology, beliefs and values of institutional, economic and political structures. From this perspective too, discourse is also a means by which people see and appreciate the world. In representing a reality, discourse locates social actors (including their micro-celebrities and their followers) in varied manners, organizes, and mediates their relationships with each other.

In the hype of micro-celebrity ustadz, the use of metaphors is very likely to help attract the people's sympathy and support. Many have suggested that metaphor is rhetorically employed for persuasion and, therefore, it might be used pervasively in media discourse, as its objective is, among other things, to persuade the recipients (readers or viewers) of the respective discourse (Charteris-Black, 2004, p. 7).

The application of a critical perspective in metaphor analysis was initially suggested by Charteris-Black (2004). Considering the persuasive nature of the use of metaphor in political speeches he believes that it is the speaker's ideology, attitude or belief which may influence his preference for a certain conceptual metaphor over another (ibid.: 41). This critical view clearly emphasizes the importance of interpreting beyond the semantic meaning of metaphor by scrutinizing the social context in which the discourse is situated.

Thus far, since the emergence of the Cognitive Linguistics (CL) theory of metaphor by Lakoff and Johnson's (1980) publication, there have been numerous metaphorical researches carried out on various aspects of economic discourse. However, most of them have focused on investigating the use of metaphor in the media (e.g. magazines and newspapers' reportings on economic issues), for instance, Bratož (2004) who crosslinguistically investigated the types of metaphors in Slovene and English Economic magazines. She revealed that both languages shared similar metaphors, such as ECONOMY IS AN ORGANISM, DOWNWARD MARKET MOVEMENTS ARE NATURAL DISASTERS, MERGER IS MARRIAGE, TAKEOVERS ARE WAR, and THE FINANCIAL MARKET IS THEATER. In addition, she emphasized that those metaphors on economic discourse found in the Slovene corpus might be transferred cross culturally from the Anglo-American concepts, although some of their linguistic realizations seem to be uniquely culture-specific.

Similarly, Urbonaitė and Šeškauskièn (2007) had a cross-linguistic investigation of HEALTH metaphor in political and economic discourse in the English-Lithuanian magazines and papers. They uncovered seven identical types of HEALTH metaphors in both languages, such as PROBLEM IS MALFUNCTION, PROBLEM IS PAIN, (MEANS OF) IMPROVEMENT IS MEDICAL TREATMENT, (GOOD) CONDITION IS (GOOD) HEALTH, LASTING TOO LONG (DISEASE) IS CHRONIC, EVALUATION IS DIAGNOSIS, and SPREAD OF IDEAS IS CONTAMINATION. They concluded that, 
although both languages shared similar types of HEALTH metaphors, Lithuanian seem to describe ailments or diseases with more specific linguistic-manifestations than English which, in line with the previously reviewed research, are deemed as culture-specific.

Furthermore, Charteris-Black and Ennis (2001) analyzed the use of metaphors in English and Spanish newspapers' financial reportings corpora. They uncovered that metaphors in the two languages shared similar conceptualizations, such as ECONOMY IS ORGANISM and MARKET MOVEMENTS AS NATURAL DISASTERS manifested in several distinct linguistic expressions pertaining to physical conflict, physical and mental health, mood, weather conditions, and earthquakes. However, quantitatively, they emphasized that there are different preferences, while on the one hand, Spanish news reporting on economics is dominated by psychological mood and personality-based metaphors, English reporting, on the other hand, prefers using nautical-related metaphors.

Unlike media-based metaphorical analyses on economic discourses, there have been few researches that investigated the metaphors in the presidential (political) speeches or took a critical approach for the analysis. Take, for example, Scacco's (2009) research that critically analyzed the use of metaphors in Obama's speeches on economic issues during the first 100 days of his presidential administration. He unveiled that Obama conceptualized the American economic crisis in three higher-level metaphors, namely (GOOD) ECONOMY IS (GOOD) HEALTH, ECONOMY IS A BUILDING, and ECONOMY IS A JOURNEY. He further specified that Obama's concept of ECONOMIC CRISIS IS A DISEASE is aimed at firmly describing the economic state to the people and its urgency for quick response or treatment. Besides, the concept of ECONOMIC POLICY IS A NEW FOUNDATION (of A BUILDING) is used to illustrate the importance of Obama's new policies for the nation's economy and thus demands support from the citizens. Finally, the concept of ECONOMY IS A JOURNEY is aimed at reminding American people of the likelihood to encounter similar crisis or economic problem in the future.

\section{METHOD}

The study employed a descriptive qualitative design. The data are obtained from two youtube channels, namely https://www.youtube.com/results?search_query=hanan+attaki+channel and https://www.youtube.com/results?search_query=UAS+channel youtube channel. Those channels provide each candidates' dakwah videos on hijrah topic. Therefore, the data took the form of utterances containing metaphoric expressions.

The data were collected through five steps (Steen, 1999). First, the identification of metaphor-related words in which an analyst needs to distinguish which words are metaphorically used by understanding the context where they occur or consulting them with a dictionary. Second, the identification of propositions among the identified metaphorically used words. Third and fourth steps, a researcher needs to identify 
comparable similarities of linguistic realizations in source and target domains and identify an analogical structure between them simultaneously. Finally, after establishing an analogical structure, the researcher drew a cross-domain mapping.

The data were analyzed qualitatively through cognitive metaphor theory proposed by Lakoff and Johnson (1980) and critical metaphor analysis by Charteris-Black (2004). The theories are applied to find out the political thought through the use of conceptual metaphors. Eventually, the researcher elucidated any possible ideological load in the use of respective conceptual metaphors at discursive level. These theories work best to find out the result of the research question because they provide a chronological analysis from how a single metaphor can lead a discourse into an acceptable concept with several ideologies inserted.

\section{DISCUSSION}

The findings indicate the use of some conceptual metaphors in the topic of Hijrah by both ustadz. UHA used various kinds of metaphors, including DOA IS A WEAPON, HIJRAH IS A JOURNEY, and SIN IS A DISEASE. Meanwhile, UAS employed a fewer types of metaphors in his dakwa speeches, namely HIJRAH (AGAINST SINFUL ACTS) IS A BATTLE and HEART IS AN OBJECT IN THE CONTAINER.

\section{Doa is a weapon}

This type of metaphor certainly conceptualized doa as a mighty tool capable of doing or changing anything (including one's destiny) beyond human perception. UHA, for instance, conceptualizes doa as a necessary element for the consistency in doing hijrah and as a weapon that will defeat any hindering factors during its process. It is evident when observing the Table 1. that indicates the linguistic forms of doa is a weapon metaphor used by UHA are manifested in the lexemes, such as 'powerful', 'menaklukkan' (to defeat), as illustrated in the Table 1. below.

Table 1. DOA IS A WEAPON Metaphor

\begin{tabular}{|c|c|c|c|c|}
\hline $\begin{array}{c}\text { No } \\
.\end{array}$ & Type & Excerpt & Lexemes & Source \\
\hline $\mathbf{1}$ & Doa is a weapon & $\begin{array}{c}\text { doa kita itu Powerful } \\
\text { Ia dapat } \\
\text { menaklukkan seluruh }\end{array}$ & $\begin{array}{c}\text { powerful, } \\
\text { menaklukkan }\end{array}$ & Cara Berhijrah \\
\hline permasalahan hidup
\end{tabular}

This kind of metaphor has particular conceptual mappings that correspond between the source and target domain. Doa shares the characteristics of the weapon as both are tools through which the shooter or prayer use to achieve a certain target or goal.

\section{Hijrah is a journey}

The second most resonant metaphor observed in UHA's data is HIJRAH IS A JOURNEY METAPHOR. This metaphor conceptualizes the the phases that every hijrah 
individual undergoes as a trip, departing from the badness to the goodness, or from the sins to the rightous acts. Also, the metaphor of this type entails some dillematic moments that one may encounter (illustrated as persimpangan 'intersection') during the journey, whether to stop and go back to where he/she embarks, or continue to reach the final destination. The journey metaphor implies that, overall, UHA aims at framing the audience to see hijrah as a continuous effort that calls for sacrifices. However, the types of sacrifices have been left unclear and lack of elaboration throughout the speech as exemplified in the Table 2.

Table 2. HIJRAH IS A JOURNEY Metaphor

\begin{tabular}{|c|c|c|c|c|}
\hline No. & Type & Excerpt & Lexemes & Source \\
\hline 2 & $\begin{array}{c}\text { Hijrah is a } \\
\text { Journey }\end{array}$ & $\begin{array}{c}\text { "Tafakur itulah yang } \\
\text { mengantarkan saya } \\
\text { kepada dakwah" } \\
\text { "Perjalanan hijrah butuh } \\
\text { pengorbanan yang tak } \\
\text { sedikit" } \\
\text { "Mungkin kalian pernah } \\
\text { berada di persimpangan } \\
\text { antara kembali atau tetap } \\
\text { istiqomah?" }\end{array}$ & $\begin{array}{c}\text { Mengantarkan, } \\
\text { perjalanan, } \\
\text { persimpangan }\end{array}$ & $\begin{array}{c}\text { Cerita Awal } \\
\text { Mula } \\
\text { Hijrahnya } \\
\text { Ustadz } \\
\text { Hanan } \\
\text { Attaqi }\end{array}$ \\
\hline
\end{tabular}

Conceptualizing hijrah in such a way may activate the frame that hijrah requires patience as it may take time to reach the level of 'better than before' person. Rhetorically, UHA's aim at using this metaphor were perhaps twofold: either to build his followers' confidence and optimism in udergoing hijrah processes by highlighting the consequences of paving the path of hijrah itself.

\section{Sin is a disease}

The third prominent metaphor in UHA's speeches is that the conceptualization of SIN IS A DISEASE metaphor. This variant of metaphor highlights our cognitive understanding that our body is weak when we suffer from an illness or get infected by a virus and, thus, its proper prevention and protection is of the importance in our lives. Therefore, such a metaphor could be potentially a persuasive tool for UHA to encourage his followers to prevent any sinful acts.

The list of keywords (see Table 3.) demonstrates how the metaphor is framed in UHA's rhetoric to describe various sins that may infect or stain one's faith. It is much evident by the metaphoric occurrences of the lexemes like gengsi 'pride', dengki 'envy', and sombong 'arrogance' through which he attempts to remind the audience and regard those acts as big threat to our faith's well-being. Further, this kind of metaphor also enables UHA to conceptualize ibadah 'worship' as a remedy for any faith's illness. 
Table 3. SIN IS A DISEASE Metaphor

\begin{tabular}{|c|c|c|c|c|}
\hline No. & Type & Excerpt & Lexemes & Source \\
\hline 3 & $\operatorname{Sin}$ is a disease & $\begin{array}{l}\text { "menyembuhkan diri dengan } \\
\text { ibadah" } \\
\text { “meredakan kesempitan hati" } \\
\text { "jika hati telah terinfeksi, sulit } \\
\text { melihat kebaikan" } \\
\text { "orang menolak karena Gengsi, } \\
\text { dengki, dan sombong, itu sebab hat } \\
\text { kotor dan sakit" }\end{array}$ & $\begin{array}{l}\text { menyembuh } \\
\text { kan, } \\
\text { meredakan, } \\
\text { terinfeksi, } \\
\text { sakit }\end{array}$ & Hijrah Itu Keren \\
\hline
\end{tabular}

\section{Hijrah (against sinful acts) is a battle}

While, UHA conceptualizes hijrah as a journey; traveling from unfavoured acts to the good deeds, UAS views it conceptually in the metaphoric sense as a battle one needs to carry out against prohibited and sinful acts respectively. Besides, through this metaphor, he conceptualizes setan 'devils' as our common enemy in doing hijrah. In addition to it, he also strongly emphasizes the importance of being in a jama'ah 'being in a group' after declaring hijrah in which he conceptualizes it as a stronger shield to protect us from the setan.

This pattern of metaphor maybe used to achieve a persuasive end, namely collectivism. For instance, in order to create solid force, one needs to gather in a group to be properly strengthened at the same time. In other words, we cannot hope to frighten our foes in the battle field unless we remain in a strong and compact group. Therefore, this metaphor may potentially evoke the audience's awareness of the importance of collective actions to avoid failure and loss in the battle, as illustrated in the following Table 4:

Table 4. HIJRAH IS A BATTLE Metaphor

\begin{tabular}{|c|c|c|c|c|}
\hline No. & Type & Excerpt & Lexemes & Source \\
\hline 1 & Hijrah is a battle & $\begin{array}{c}\text { "berjamaah kita terselamatkan } \\
\text { kawan-kawan" } \\
\text { "setan akan menerkam } \\
\text { kadang-kadang setan tidak } \\
\underline{\text { terlalu kuat" }} \\
\text { "kita ter } \\
\text { us waspada kita terus kontrol" }\end{array}$ & $\begin{array}{c}\text { tidak terlalu } \\
\text { kuat, } \\
\text { terselamatkan, } \\
\text { menerkam, } \\
\text { waspada, } \\
\text { kontrol }\end{array}$ & $\begin{array}{c}\text { Tantangan } \\
\text { Setelah } \\
\text { Hijrah }\end{array}$ \\
\hline
\end{tabular}




\section{CONCLUSION}

The CMA appoach proposed by Charteris-Black (2004) combines the conceptual (cognitive) semantic and pragmatic analyses of the metaphor usage by the politicians (e.g., the President) on economic discourses may help us reveal that metaphor as an effective rhetorical device to manifest their ideological stance to the public and persuade them to believe it as justifiable truth. By applying that approach, the present study demonstrates that both UHA and UAS use different types of source domain metaphors on the one hand, notwithstanding it also shows few diverse (linguistic) realizations that are adjusted and conditioned in accordance to the objectives and the context of each event on the other hand.

However, further studies are necessary to provide stronger evidence particularly on the notion of whether these metaphors are also confirmed across cultures and nations with different geopolitical landscapes. In addition, since the present study takes a general description of the use of metaphor in both UHA and UAS' speeches, the direction of the future research could focus on looking at a certain point of time within their speeches with much greater and more detailed description of the metaphor types in use, values, or ideological contestations. Even more challenging, future studies may also be extended to specifically examine the shifts in the use of metaphor and its ideological tendencies of religious speeches on hijrah or other trending topics at any particular time.

\section{REFERENCES}

Abdel-Raheem, A. (2013). Metaphor of the global financial crisis after 2008: reconstructing confidence by Arab and Western financial medias. Sciences de la société, 88, 160-182.

Bratož, S. (2004). A comparative study of metaphor in english and slovene popular economic discourse. Managing Global Transitions. 2. Accessible in: http://www.fmkp.si/zalozba/ISSN/1581-6311/2 179-196.pdf.

Charteris-Black. (2004). Corpus Approaches to Critical Metaphor Analysis. New York. Palgrave.

Charteris-Black. (2006). Britain as a container: immigration metaphors in the 2005 election campaign.

Goatly, A. (2007). Washing the brain: Metaphor and hidden ideology. Amsterdam: John Benjamins Pub. Co.

Ko"vecses, Z. (2002). Metaphor: a practical introduction. New York: Oxford University Press.

Lakoff, G. (1993). The Contemporary Theory of Metaphor. In Ortony, A., Ed. Metaphor and thought. Cambridge: Cambridge University Press., p. 202-252.

Lakoff, G., \& Johnson, M. (1980). Metaphors we live by. Chicago: University of Chicago Press.

Landau, M. J., \& Robinson, M. D. (2014). The power of metaphor: Examining its influence on social life. Washington: American Psychological Association. 
O'mara-Shimek, M., Parra, M. G., \& Larrea, A. O. (2015). Stop the bleeding or weather the storm? crisis solution marketing and the ideological use of metaphor in online financial reporting of the stock market crash of 2008 at the New York Stock Exchange. Discourse \& Communication, 9, 1, 103-123.

Steen, G. J (1999). From linguistic to conceptual metaphor in five steps. In Gibbs, R. W., \& Steen, G. J. (Ed.). Metaphor in cognitive linguistics: Selected papers from the 5th International Cognitive Linguistics Conference, Amsterdam, 1997. Amsterdam: John Benjamins, p. 57-77.

Scacco, J. (2009). Shaping economic reality: a critical metaphor analysis of president barack Obama's economic language during his first 100 days. Gnovis, 10, 1. Retrieved September, 102019 from: http://gnovisjournal.org/2009/12/22/shaping-economic-realitycritical-metaphor-analysis-president-barack-Obama-s-economic-language/). 
52 I Zainur Rofiq 